Reprod. Nutr. Dévelop., 1982, 22 (4), 631-640.

\title{
Variations of metabolism and feed efficiency in laying R.I.R.-hens in relation to prenatal environmental temperatures
}

\author{
R. GEERS, H. MICHELS
}

Laboratorium voor Eco-Fysiologie der Huisdieren, K.U. Leuven, Kardinaal Mercierlaan 92, B-3030 Heverlee, Belgium.

Summary. Starting from an hypothesis concerning the long-term effects of exogenous treatment during the ontogeny of mammals and birds, we incubated Rhode Island Red (RIR) eggs at different prenatal temperatures (table 1) to study the feed efficiency, development, reproduction and energy metabolism of the hens. The maintenance requirement varied (up to $30 \mathrm{p} .100$ ) as well as the feed conversion (up to $28 \mathrm{p} .100$ ), but lower maintenance requirements did not always result in a significantly higher net energy gain nor in a higher feed efficiency above maintenance. Laying RIR hens from eggs incubated at $37.8^{\circ} \mathrm{C}$ vs those from eggs incubated at 36.8 and $35.8^{\circ} \mathrm{C}$ (days $1-10$ ) showed a significantly $(P \leqslant 0.05)$ lower fasting heat production, resulting in lower maintenance requirement and higher energy balance mainly composed of fat energy. This was paralleled by a lower feed conversion rate during growth and reproduction. In fasting conditions, these animals showed a lower oxidative metabolism of fats and proteins.

\section{Introduction.}

It has been shown that incubation temperature can affect postnatal growth in domestic fowl (Romanoff, 1935, 1936 ; Muambi, 1974 ; Michels et al., 1974 ; Decuypere, 1979) as well as egg production, feed consumption, heat production, hematocrit and serum TSH levels in laying RIR hens (Michels et al., 1980).

In the present study, we focused our attention on the possible relationships between heat production, maintenance requirements, feed efficiency and some criteria of intermediate metabolism in order to test the hypothesis that exogenous factors, intervening during prenatal ontogenesis, can affect growth and reproduction in mammals and birds. This implicates the possibility of optimizing the quantitative and qualitative food energy flow to man (Michels, 1972, 1976a, 1976b).

\section{Materials and methods.}

Six groups of 120 eggs each, taken from a pure-bred flock of nearly oneyear old Rhode Island Red (RIR) hens (Gallus gallus L.) (University Breeding Centre for Laboratory Animals), were incubated at different temperatures 
TABLE 1

Number of eggs and pullets in relation to incubation temperatures during each of two series of experiments

\begin{tabular}{ccccccc}
\hline Group & Eggs & Days 1-10 & Days $11-17$ & Day 17-hatch & $\mathrm{C}$ & $\mathrm{P}$ \\
\hline 1a & 120 & $35.8^{\circ} \mathrm{C}(\mathrm{V} 1)$ & $37.8^{\circ} \mathrm{C}$ & $33.5^{\circ} \mathrm{C}$ & 6 & 2 \\
1b & 120 & $35.8^{\circ} \mathrm{C}(\mathrm{V} 1)$ & $37.8^{\circ} \mathrm{C}$ & $37.5^{\circ} \mathrm{C}$ & 6 & 2 \\
$2 \mathrm{a}$ & 120 & $36.8^{\circ} \mathrm{C}(\mathrm{V} 2)$ & $37.8^{\circ} \mathrm{C}$ & $33.5^{\circ} \mathrm{C}$ & 6 & 2 \\
$2 \mathrm{~b}$ & 120 & $36.8^{\circ} \mathrm{C}(\mathrm{V} 2)$ & $37.8^{\circ} \mathrm{C}$ & $37.5^{\circ} \mathrm{C}$ & 6 & 2 \\
3a & 120 & $37.8^{\circ} \mathrm{C}(\mathrm{V} 3)$ & $37.8^{\circ} \mathrm{C}$ & $33.5^{\circ} \mathrm{C}$ & 6 & 2 \\
$3 \mathrm{~b}$ & 120 & $37.8^{\circ} \mathrm{C}(\mathrm{V} 3)$ & $37.8^{\circ} \mathrm{C}$ & $37.5^{\circ} \mathrm{C}$ & 6 & 2 \\
\hline
\end{tabular}

$C$ : number of chickens $(Q)$ at 7 weeks of age ; P : number of pullets used in metabolic trials.

(summarized in table 1), the other environmental conditions being standard. The following year, we repeated this experiment to check the reproducibility of our results since only a limited number of animals could be used in our metabolic trials.

After hatching, the chickens were raised in constant environmental conditions. Prehatching, incubation and rearing conditions have already been described in detail elsewhere (Geers et al., 1978b ; Decuypere, 1979). When 7 weeks old, 6 pullets, chosen at random from each incubation group (table 1), were put into individual cages without visual contact in order to prepare them for individual metabolic trials.

From 7 weeks on, individual body weight $( \pm 0.1 \mathrm{~g})$ and feed intake $( \pm 0.1 \mathrm{~g})$ were followed every week till the onset of laying, and then every 4 weeks till the age of 100 weeks with a precision of $\pm 5 \mathrm{~g}$. Individual egg production was measured every day by collection and weighing $( \pm 0.1 \mathrm{~g})$.

From 6 to 10 months of postnatal age, two animals were taken at random from each group for one-week metabolic experiments that were divided into three subperiods : $A$ (days $1-2$ at $25{ }^{\circ} \mathrm{C}$ ) and $B$ (days $3-4$ at either $35,30,25,20$, 15,10 or $5{ }^{\circ} \mathrm{C}$ in experiment 1 or $25-5^{\circ} \mathrm{C}$ in experiment 2 ) in feeding conditions, and $C$ (days $5-7$ ) in fasting conditions. Since measurements were made at different environmental temperatures, the same animals had to be used several times (table 2) so that interindividual variations between temperatures would not interact.

TABLE 2

Postnatal experimental temperatures $\left(\mathrm{OT}{ }^{\circ} \mathrm{C}\right)$

$\begin{array}{llllllll}{ }^{\circ} \mathrm{C} & 25 & 30 & 35 & 20 & 15 & 10 & 5 \\ \mathrm{~K} 1 & \mathrm{a} 1 & \mathrm{~b} 2 & \mathrm{a} 1 & \mathrm{a} 1 & \mathrm{~b} 2 & \mathrm{a} 1 & \mathrm{~b} 2 \\ \mathrm{~K} 2 & \mathrm{~b} 1 & \mathrm{a} 2 & \mathrm{~b} 1 & \mathrm{~b} 1 & \mathrm{a} 2 & \mathrm{~b} 1 & \mathrm{a} 2\end{array}$

$\mathrm{K} 1, \mathrm{~K} 2$ : respiration chambers; a : experimental animals of the $33.5^{\circ} \mathrm{C}$ group (day 17-hatch) ; $\mathrm{b}$ : experimental animals of the $37.5^{\circ} \mathrm{C}$ group (day 17 -hatch) or 4 animals per $\mathrm{V}$ group (V1, V2, $\mathrm{V} 3$, see table 1). 
The metabolic experiments were carried out in two open-circuit respiration chambers (Geers et al., 1978b) which had been used formerly as incubators (Michels et al., 1974). Oxygen uptake and carbon dioxide output were measured by the diaferometer method (Romijn and Lokhorst, 1966 ; Geers et al., 1978a). The ventilation rate was calculated for standard conditions (Van Es, 1961). The calculation of heat production by this method (Romijn and Lokhorst, 1961) was adapted for $\mathrm{kJ}$, and we were able to derive the energy gain from the metabolizable energy ; data obtained from carbon and nitrogen balances (Farrell, 1974) confirm this method and are not discussed here.

Before and after each subperiod, we weighed the feed intake, excreta and egg production of each hen. After storage, we analyzed the samples according to the method of Michels et al. (1974), but used an adiabatic calorimeter (IKA C400, Janke \& Kunkel KG, Staufen) for energy analysis. The macro-Kjeldahl method was used to analyze nitrogen. Carbon was determined by the method of Nijkamp (1965). Excreta were dried at $65^{\circ} \mathrm{C}$ in a vacuum oven for $24 \mathrm{hrs}$.

Energy gained as fats and proteins was calculated as described by Farrell (1974). The contribution of carbohydrates, fats and proteins to oxidative metabolism was calculated by multiple regression equations. Since the literature (e.g. Wöhlbier, 1974) has described the common main biochemical pathways in all animal species, we obtained the multiple regression equations from the calculations of the contribution of carbohydrates $(C)$, fats $(F)$ and proteins $(P)$ to catabolism published by Van Kampen (1975) :

$\mathrm{C}(\mathrm{g} / \mathrm{t})=3.9311 \mathrm{CO}_{2}(1 / \mathrm{t})-2.7839 \mathrm{O}_{2}(1 / \mathrm{t}) \mathrm{r}=0.997 \mathrm{~s}_{\mathrm{e}}=1.53$

$\mathrm{F}(\mathrm{g} / \mathrm{t})=-1.8685 \mathrm{CO}_{2}(1 / \mathrm{t})+1.7755 \mathrm{O}_{2}(1 / \mathrm{t}) \mathrm{r}=0.992 \mathrm{~s}_{\mathrm{e}}=0.61$

$\mathrm{P}(\mathrm{g} / \mathrm{t})=0.5767 \mathrm{CO}_{2}(1 / \mathrm{t})-0.3135 \mathrm{O}_{2}(1 / \mathrm{t}) \mathrm{r}=0.998 \mathrm{~s}_{\mathrm{e}}=0.90$

where $t=$ unit of time; $r=$ correlation coefficient (15 degrees of freedom) ; $\mathrm{s}_{\mathrm{e}}=$ standard error.

The data were analyzed by simple linear regression equations and analysis of covariance (Winer, 1971 ; Dixon, 1975). The normal distribution of the data and the homogeneity of variances between groups (prenatal temperature treatment) were proved by analyzing skewness and kurtosis and by the Bartlett test (Wonnacott and Wonnacott, 1972 ; Dixon, 1975). No interactions between preand postnatal environmental treatments were observed. Consequently, for the analysis of each possible effect, the animals were grouped together into larger numbers. During the metabolic trials we observed no intergroup differences in body weight (table 3) and no relationship between body weight and heat production (Geers et al., 1978b). Hence, it was not necessary to refer to body weight when analyzing and discussing the data.

\section{Results and discussion.}

Table 3 summarizes the mean values and standard deviations of body weight (FBW g) after 3 days of fasting during the metabolic trials, feed consumption ( $F C \mathrm{~g}$ ) and egg production ( $\mathrm{EP} \mathrm{g}$ ) for several 4-week periods during laying. 


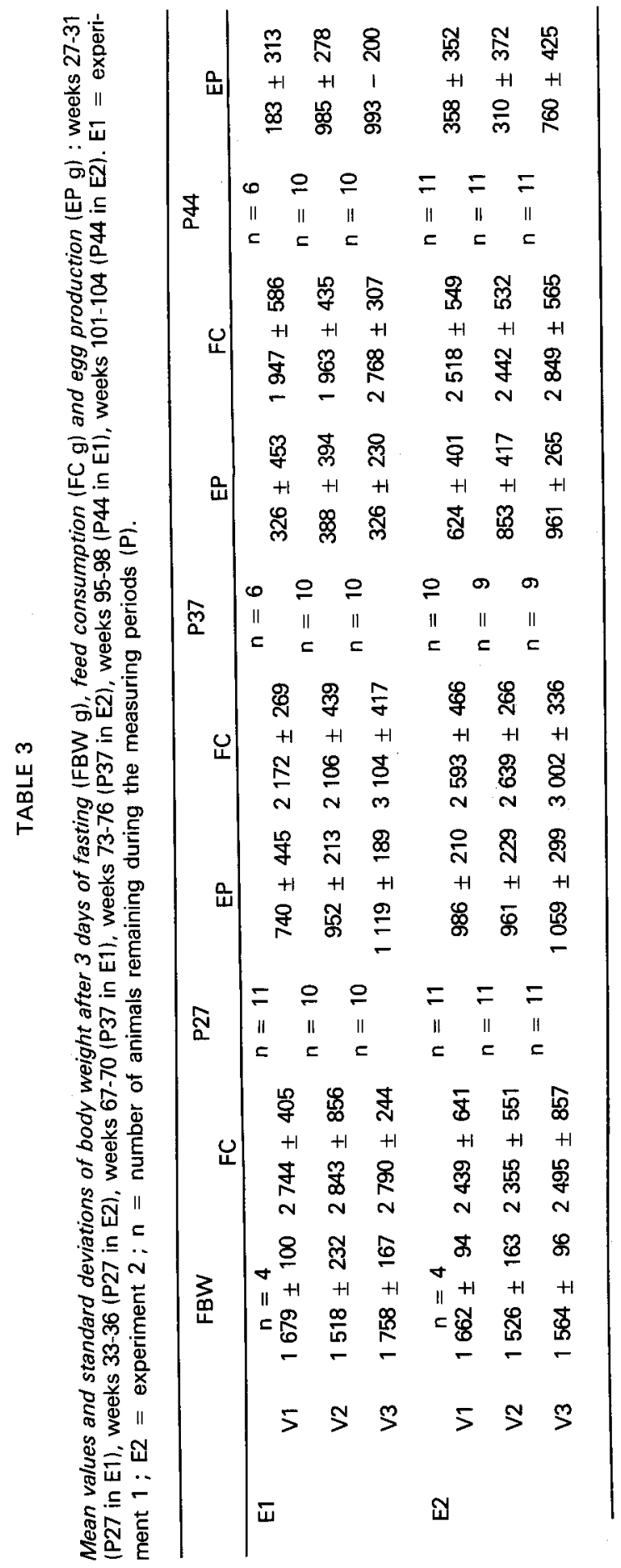


TABLE 4

Feed conversion rate during growth and reproduction in experiments 1 (E1) and 2 (E2).

a) $g$ feed intake/g weight gain during weeks 7 to 12 ;
E1 V1 $5.81 \pm 0.27(n=12)$
V2 $5.41 \pm 0,27(n=11)$
V3 $4.87 \pm 0.37(n=12)$
E2 V1 $5.08 \pm 0.22(\mathrm{n}=12)$
V2 $4.99 \pm 0.34(n=12)$
V3 $4.53 \pm 0.29(n=11)$

b) $g$ feed intake/g eggs during, weeks 27 to 47 in $E 1$ and during weeks 33 to 53 in E2 :
E1 V1
V2 $2.93 \pm 0.30(n=10)$
V3 $2.46 \pm 0.21(n=10)$
E2 V1 $3.05 \pm 0.51(n=11)$
V2 $2.83 \pm 0.41(n=11)$
V3 $2.46 \pm 0.24(n=11)$

Mean values with a confidence interval $(P \leq 0.05) . n=$ number of measurements $;(-)=$ no measurements.

In both experiments, the V3 hens (table 1) had a lower feed conversion rate during egg production (weeks 27-47 in experiment 1 ; weeks 33-53 in experiment 2) (table 4), as confirmed by the analysis of variance. We gave special attention to the data on the metabolic trials when studying the results.

With regard to the usual metabolic data on digestion, absorption and assimilation times (Bell and Freeman, 1971), data from subperiods A and B (days 1-4) were grouped together in order to relate feed intake to elimination of excreta and production of heat, eggs and tissues. The hens received the same feed as before but showed variations in feeding level which might have been individual differential reactions to the respiration chamber environment, even though there was well-established auditive contact with the poultry house by interphone.

Notwithstanding the short duration of the metabolic trials and the limited number of hens used, we obtained the following results. Neither experiment showed any significant effects of incubation temperatures (days 17 to hatching) on heat production and energy or on nitrogen and carbon balance. But laying hens in fasting conditions, hatched from eggs incubated at $37.8^{\circ} \mathrm{C}$ (days $1-10$ ) (V3), had a statistically lower heat production when compared to the other groups $(P \leqslant 0.05)$, as shown by experiment 1 (E1) (fig. 1). These variations in

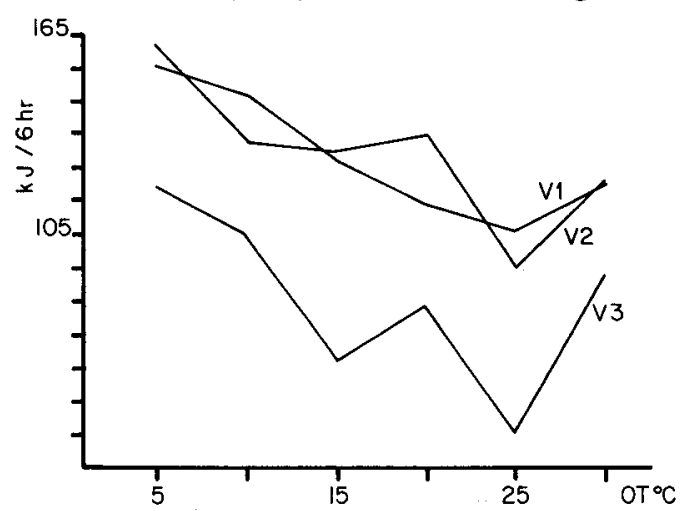

FIG. 1. - The relationship between heat production ( $k J / 6 \mathrm{hr}$ ) and postnatal environmental temperature (OT ${ }^{\circ} \mathrm{C}$ ) during metabolic trials for $E 7$ (groups $1,2,3$ ); measurements were taken during darkness from 60 to 66 hrs of fasting. Each curve represents data on 2 animals measured at different temperatures. The ages, the same between groups but not between temperatures $\left(\mathrm{OT}{ }^{\circ} \mathrm{C}\right)$, varied from 6 to 10 months. Each point represents one animal. 
TABLE 5

Fats $(\mathrm{g} / 72 \mathrm{hr})$ and proteins $(\mathrm{g} / 72 \mathrm{hr}$ ) catabolized during fasting (days 5-7) in experiment 2. Mean \pm SD was calculated on individual measurements.

$\begin{array}{lll}\text { Fats } & V 139.9 \pm 9.06 & V 1 \neq V 2(P \leq 0.02) \\ & V 230.9 \pm 8.44 & \\ & V 327.3 \pm 6,56 & V 1 \neq V 3(P \leq 0.002) \\ \text { Proteins } & V 18.31 \pm 1.43 & V 1 \neq V 3(P \leq 0.001) \\ & V 28.12 \pm 0.901 & V 2 \neq V 3(P \leq 0.001) \\ & V 35.99 \pm 1.41 & \end{array}$

heat production in relation to prenatal environmental temperatures were similar to those observed in mammals under different postnatal environmental temperatures (Hart, 1957). No measurements of body temperature or heat insulation were taken. The V3 animals in experiment 2 (E2) had a lower oxidative metabolism of fats and proteins during subperiod $C$ (table 5), but showed no differences in carbohydrates.

When subperiods $A$ and $B$ (in feeding conditions) were grouped together, the V3 animals showed a lower maintenance requirement, calculated as metabolizable energy (ME) intake for zero net energy gain, and a higher energy gain (NE). Intergroup differences were statistically significant $(P \leqslant 0.05)$ only in experiment 2 (fig. 2), as shown by the analysis of covariance. Thus, differences

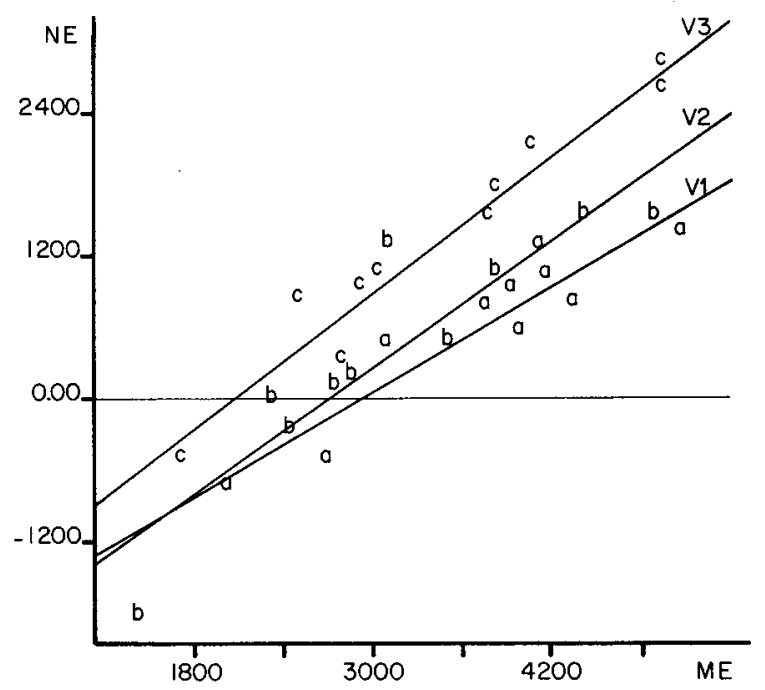

FIG. 2. - The relationship between net energy production (NE kJ/96 hr) and metabolizable energy intake (ME kJ/96 hr) for E2 (day 1-4).

$$
\begin{aligned}
& \text { V1(a) } b=0.741 \quad r=0.928+n=10 \quad A C M=380 \\
& \text { V2(b) } b=0.885 \quad r=0.902+n=10 \quad A C M=682 \\
& \text { V3(c) } b=0.951 \quad r=0.979+n=10 \quad A C M=1367 \\
& \mathrm{dACM}=+
\end{aligned}
$$

b : regression coefficient : $y=b x+a ; r:$ correlation coefficient; $\mathbf{n}$ : number of measurements ; (number of animals, see table 2) ACM : adjusted cell mean (Dixon, 1975) ; $d$ : difference ; + : statistically significant for $P \leqslant 0.05$. 
in net energy were due to variations in maintenance requirements rather than to a different partitioning of metabolizable energy to egg production or to body weight gain, as suggested by Garrett (1980).

On the basis of the covariance analysis, no significant differences were found in net energy produced as proteins, and the higher net energy balance gain of the $V 3$ animals in experiment 2 was again found to be fat (fig. 3). The precise values for maintenance metabolism and for fat gain leggs and tissues taken together), derived from this figure and from the regression coefficients, prove once more the predominate effect of variations in maintenance metabolism. Our results are in agreement with those of Thorbek (1969) who found that efficiency of utilization of metabolizable energy in growing pigs increased with increasing fat gain in relation to total energy gain. A higher heat increment for protein synthesis in comparison to fat synthesis was found in poultry (Farrell, 1974). Although there were no differences in b-coefficients, a similar trend above maintenance requirements is evidenced when comparing the b-values of the regression equations of the relationships of ME with NE and VE, respectively (figs. 2,3 ).

Besides the relative importance of individual variability within small samples of animals, possible interactions with the behavioural activities of the animals (Wenk and Van Es, 1976; Van Kampen, 1976) may explain the lack of significance in experiment 1 .

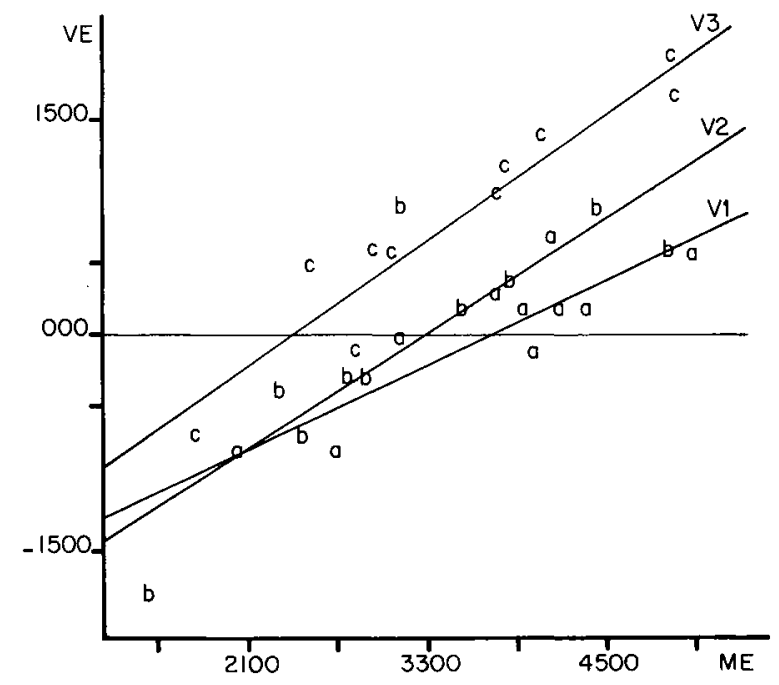

FIG. 3. - The relationship between fat energy production (VE $=\mathrm{kJ} / 96 \mathrm{hr}$ ) and metabolizable energy intake ( $\mathrm{ME}=\mathrm{kJ} / 96 \mathrm{hr}$ ) for $E 2$ (day 1-4).

$$
\begin{array}{lllll}
V 1(a) & b=0.497 & r=0.883+n=10 & A C M= & 145 \\
V 2(b) & b=0.679 & r=0.855+n=10 & A C M= & 141 \\
V 3(c) & b=0.745 & r=0.960+n=10 & A C M= & 811
\end{array}
$$

(for symbols see fig. 2). 
The structures and mechanisms of neurohormonal control are differentiated in chick embryos during the first 10 days of incubation (Freeman and Vince, 1974). Widdowson (1975) thought these differentiation periods were the most sensitive ones to long-term action by exogenous factors, taking into account the possibility of selection as a result of differential mortality (Barnett et al., 1975). Moreover, the question of whether acquired information can be transmitted through successive generations of cells may also be invoked. The approach of Zeuthen (1953), which relates variations in postnatal heat production to mechanisms of phylogeny and ontogeny, must be taken into consideration in this respect.

\section{Conclusions.}

During two independent experiments, the variation in energy metabolism and feed efficiency in laying RIR hens, originating from a homogeneous population, were related to prenatal environmental temperatures.

The higher net energy gains and lower feed conversion rates of the hens incubated at $37.8{ }^{\circ} \mathrm{C}$ (days $1-10$ ) vs those incubated at 36.8 and $36.8{ }^{\circ} \mathrm{C}$ were explained by their lower maintenance requirements, resulting from a lower oxidative metabolism of fats and proteins measured during fasting.

No differences in efficiencies in gain of net energy, proteins or fats above maintenance were observed.

The design of our successive well-standarized experiments and the use of appropriate statistical methods permitted us to observe the reproducible longterm effects of prenatal environmental temperatures in the domestic fowl. Experiments with larger numbers of hens are now in progress.

Reçu en décembre 1981. Accepté en février 1982.

Résumé. Partant d'une hypothèse concernant des effets à long terme de variables introduites au cours de l'ontogenèse, nous avons incubé des œufs de poules de la race Rhode Island Red (RIR) à des températures différentes $\left[35,8-36,8\right.$ ou $37,8{ }^{\circ} \mathrm{C}$ pendant les premiers jours (tabl. 1)]. Dans la présente publication nous analysons des critères se rapportant au métabolisme énergétique au cours de la période de ponte. Nous avons observé des différences allant jusqu'à $30 \mathrm{p}$. 100, et une diminution du besoin d'entretien, suite à l'une des températures d'incubation $\left(37,8^{\circ} \mathrm{C}\right)$. De toute façon les poules en ponte provenant des œufs incubés à $37,8^{\circ} \mathrm{C}$ au cours des dix premiers jours, présentaient en chambres respiratoires, à jeân, une production de chaleur statistiquement $(P \leqslant 0,05)$ inférieure à celles des autres lots dans les deux expériences (fig. 1). Les besoins d'entretien étaient inférieurs et les quantités d'énergie fixée supérieures (fig. 2), mais la différence n'était significative que dans la deuxième expérience. Les indices de consommation, mesurés pendant 5 semaines au cours de la croissance et pendant 20 semaines au cours de la période de ponte (tabl. 4) étaient significativement inférieurs pour le même groupe dans les deux expériences $(P \leqslant 0,05)$. Les différences constatées pour le métabolisme énergétique étaient associées, en ponte, à une lipogenèse plus intense et, à jeûn, à un catabolisme oxydatif plus faible des lipides et des protéines. 


\section{References}

BARNETT S. A., MUNRO K. M. H., SMART J. L., STODDART R. C., 1975. House mice bred for many generations in two environments. $J$. Zool., 177, 153-169.

BELL D. J., FREEMAN B. M., 1971. Physiology and biochemistry of the domestic fowl. Acad. Press, London.

DECUYPERE E., 1979. Onderzoek naar differentiële effecten van broedtemperatuurschema's op morfogenetische, fysiologische en voortplantingscriteria bij proefdieren van een R.I.R.pluimveepopulatie. Agricultura, 27, 65-280.

DIXON W. J., 1975. BMDP. Biomedical computer programs. Univ. California Press, Berkely.

FARRELL D. J., 1974. General principles and assumptions of calorimetry, 1-24. In MORRIS T. R., FREEMAN B. M., Energy requirements of poultry. Longman, Edinburgh.

FREEMAN B. M., VINCE M. A., 1974. Development of the avain embryo. Chapman and Hall, London.

GARRETT W. N., 1980. Use of energy in reproduction and lactation, 383-389. In MOUNT L. E., Energy metabolism. Butterworths, London.

GEERS R., MICHELS H., DECUYPERE E., 1978a. Advances in a method for gas analysis in metabolic experiments. Improved calibration of a Noyons diaferometer. Ann. Biol. anim. Bioch. Biophys., 18, 1309-1315.

GEERS R., MICHELS H., DECUYPERE E., 1978b. A critical analysis of fasting metabolism data in R.I.R.-hens (Gallus gallus L.). Ann. Biol. anim. Bioch. Biophys., 18, 1363-1369.

HART J. S., 1957. Climatic and temperature-induced changes in the energetics of homeotherms. Rev. Can. Biol., 16, 133-174.

MICHELS H., 1972. Onderzoeksontwerp omtrent de invloed van de omgevingstemperatuur op de stofwisseling en de levensduur bij kippen, $19 \mathrm{pp}$. (unpublished).

MICHELS H., 1976a. Zoötechniek en wereldvoedselproblemen. Tijdschr. Diergeneesk., 101, 1378-1379.

MICHELS H., 1976b. Ecologische aspekten van dierprodukties in de tropen, 45-46. In W. K. HIRSCHFELD, Liber amicorum, Witsers, Os.

MICHELS H., DECUYPERE E., GEERS R., 1980. Production and physiological criteria in laying R.I.R.-hens in relation to prenatal and postnatal environmental temperatures, 371-375. In MOUNT L.E., Energy metabolism. Butterworths, London.

MICHELS H., GEERS R., MUAMBI S., 1974. The effect of incubation temperature on pre- and posthatching development in chickens. Brit. Poult. Sci., 15, 517-523.

MUAMBI S., 1974. Etude des critères de croissance prenatal et postnatale chez la race de volaille R.I.R. en fonction des différentes températures environnantes. Agricultura, 22, 1-60.

NIJKAMP H. J., 1965. Some remarks about the determination of the heat of combustion and the carbon content of urine, 147-159. In BLAXTER K. L., Energy metabolism. Acad. Press, London.

ROMANOFF A. L., 1935. Influence of incubation temperature on the hatchability of eggs, postnatal growth and survival of turkeys. J. agric. Sci., 25, 318-525.

ROMANOFF A. L., 1936. Effect of different temperatures in the incubator on the prenatal and postnatal development of the chick. Poult. Sci, 15, 311-315.

ROMIJN C., LOKHORST W., 1961. Some aspects of energy metabolism in birds. E.A.A.P., 10, 49-59.

ROMIJN C., LOKHORST W., 1966. Improved gas analysis in metabolic experiments. Second communication. Acta physiol. pharmacol. neerl., 14, 1-11.

THORBEK G., 1969. Studies on the energy metabolism of growing pigs, 281-291. In BLAXTER K. L., KIELANOWSKI J., THORBEK G., Energy metabolism of farm animals. Oriel Press, Newcastle upon Tyne.

VAN ES A. J. H., 1961. Between-animal variation in the amount of energy required for the maintenance of cows, 1-116. Pudoc. Wageningen. 
VAN KAMPEN M., 1975. Energiemetabolism en warmteregeling van de Witte Leghorn-hen, 1-85, $\mathrm{Ph}$. D. thesis, Utrecht.

VAN KAMPEN M., 1976. Activity and energy expenditure in laying hens. J. agric. Sci., 87, 81-89.

WENK C., VAN ES A. J. H., 1976. Energy metabolism of growing chickens as related to their physical environment, 189-193. In VERMOREL M., Energy metabolism of farm animals. De Bussac, Clermont-Ferrand.

WIDDOWSON E. M., 1975. Maternal nutrition and somatic development of the foetus. Mod. Probl. Paediat., 14, 68-74.

WINER B. J., 1971. Statistical princip/es in experimental design. McGraw Hill, London.

WÖHLBIER W., 1974. Remarks about the history of the research on energy metabolism. E.A.A.P., $14,1-8$

WONNACOTT T. H., WONNACOTT R, J., 1972. Introductary statistics. Wiley, New York.

ZEUTHEN E., 1953. Oxygen uptake as related to body size in organisms. Quat. Rev. Biol., 28, 1-12. 